\title{
Augmenting in Situ Lake Level Measurements with Earth Observation Satellites
}

\author{
Ahmet Emre TEKELI' ${ }^{1}$
}

\begin{abstract}
In this article, Ice, Cloud and Land Elevation Satellite (ICESat) altimeter data were used with Moderate Resolution Imaging Spectroradiometer (MODIS) snow cover maps to determine Akşehir Lake/wetland water levels, which dried up in 2008. Since the water level dropped below the gage in 2004, the ICESAT-MODIS (ICEM)-based lake water levels could not be compared with gage levels. Instead, combined use of Landsat satellite based lake surface area studies and Akşehir Lake bathymetry (LAB) enabled ICEM assessment. ICEM and LAB differences are between $-0.09 \mathrm{~m}$ and $0.32 \mathrm{~m}$ and close to the standard deviations (s.d.) of pure ICESat-based studies $(0.02 \mathrm{~m}-0.27 \mathrm{~m})$. The minimum and maximum water surface elevation changes of ICEM between consecutive winter and spring are $0.30 \mathrm{~m}$ and $1.35 \mathrm{~m}$ and are in the historical range. ICEM showed highest s.d. during October 2005, when the wind velocities were highest.
\end{abstract}

Keywords: ICESat, GLA14, laser altimeter, Akṣehir Lake, water level, MODIS, landsat, drying lake.

\section{INTRODUCTION}

Wetlands, in addition to the water they hold, have been considered important ecosystems due to the ecological and biological diversity that inhabit them. The diminishing fresh water resources in addition to the rising population have increased the importance of protection and sustainable management of wetlands. Turkey is considered an important nation in the Middle East and Europe, having wetlands with different ecological characteristics and being on two out of four important bird migration routes in the West Palearctic Region [1]. As wetlands are sensitive areas from ecological and biological perspectives, monitoring and sustainable management of wetlands have been topics of many environmental studies. The Lakes Region, located in southwestern Turkey, includes a number of lakes and wetlands that have been included in the Wetlands Treaty -also known as the Ramsar Treaty [2]. Unfortunately, water levels of lakes in the Lakes Region have been declining due to the changing climate. Akșehir Lake/Wetland (AL/w), being among the five biggest lakes in the region, has

\section{Note:}

- This paper has been received on October 02, 2017 and accepted for publication by the Editorial Board on July $04,2018$.

- Discussions on this paper will be accepted by January 31, 2019.

- DOI: $10.18400 /$ tekderg.341316

1 Çankırı Karatekin Uni., Dep. of Civil Engineering, Çankırı, Turkey - ahmetemretekeli@karatekin.edu.tr 
experienced reduction of water levels [3-5]. Water levels in AL/w had been measured by gage level readings that were made during on-site visits performed monthly since 1975 . However, in 2004 AL/w's water level had fallen below the gage's level. Since then, no water level reading has been obtained. AL/w totally dried up in 2008.

In-situ gage measurements form the backbone of main data collection for environmental studies and provide ground truth observations for accuracy assessment of Earth observation satellites. However as in AL/w case, gage(s) can be obsolete for various reasons such as climate change and/or human intervention. Moreover, owing to initial investment and operational costs, installing gages everywhere is not possible. Besides, in-situ observations may not provide the high temporal and spatial data required, such as when monitoring lakes and wetlands. Remote sensing (RS), especially with high temporal and spatial data availability spaceborne RS, have long been used in wetland area and lake water level monitoring [6-8]. Remotely-sensed images obtained from different regions of electromagnetic spectrum optic [9,10] and radar [11-13] have long been used primarily in the detection and monitoring of changes in lakes and wetlands. Besides, water levels in these sensitive areas have also been investigated as a secondary mission.

With its long history, Landsat provides a large remotely-sensed image database that can be used in different studies focusing on change detection such as forestry, urban growth, water resource management [14-19]. There are studies demonstrating successful applications of Landsat imagery in water resource management $[3,4,5,20,21]$. The aforementioned studies investigated either lake surface variations or coastline changes of Turkish lakes using Landsat images.

Geoscience Laser Altimeter System (GLAS) is the first spaceborne laser altimeter that enabled water level measurements from space [22] between February 2003 and February 2010. To the best of author's knowledge, no accuracy assessment of GLAS-derived water surface elevations over Turkish Lakes have yet been performed.

In this study, the usability of GLAS-derived water surface elevations (WSE) over AL/w, Turkey is tested. What makes this study distinct from previous GLAS studies is that AL/W completely dried in 2008. During the recession, water surface elevations of AL/w are derived from GLAS measurements. Since WSE fell below the gage's level in 2004, GLAS-derived WSE could not be compared with in-situ observations. Instead, GLAS-derived WSE are compared using WSE obtained from the combined use of lake bathymetry and lake surface area information obtained from Landsat satellite images. The general concept of in-situ measurements is to provide ground truth observations to remote sensing. However, as indicated in this study, the combined use of various satellite-based Earth observations can provide WSE of a drying lake during its recession and supply additional information to environmental studies even in cases where in-situ observations may be inadequate or unavailable.

\section{THE STUDY AREA}

Akşehir Lake/wetland (AL/w), located in the Akarçay Basin between $38^{\circ} 24^{\prime}-38^{\circ} 37^{\prime} \mathrm{N}$ latitudes and longitudes $31^{\circ} 18^{\prime}-31^{\circ} 35^{\prime} \mathrm{E}$ (Figure 1a), is an important lake among the seven 
other lakes in the Lakes Region (LR) of Turkey [23] and is known to be the fifth biggest lake in Turkey [24].

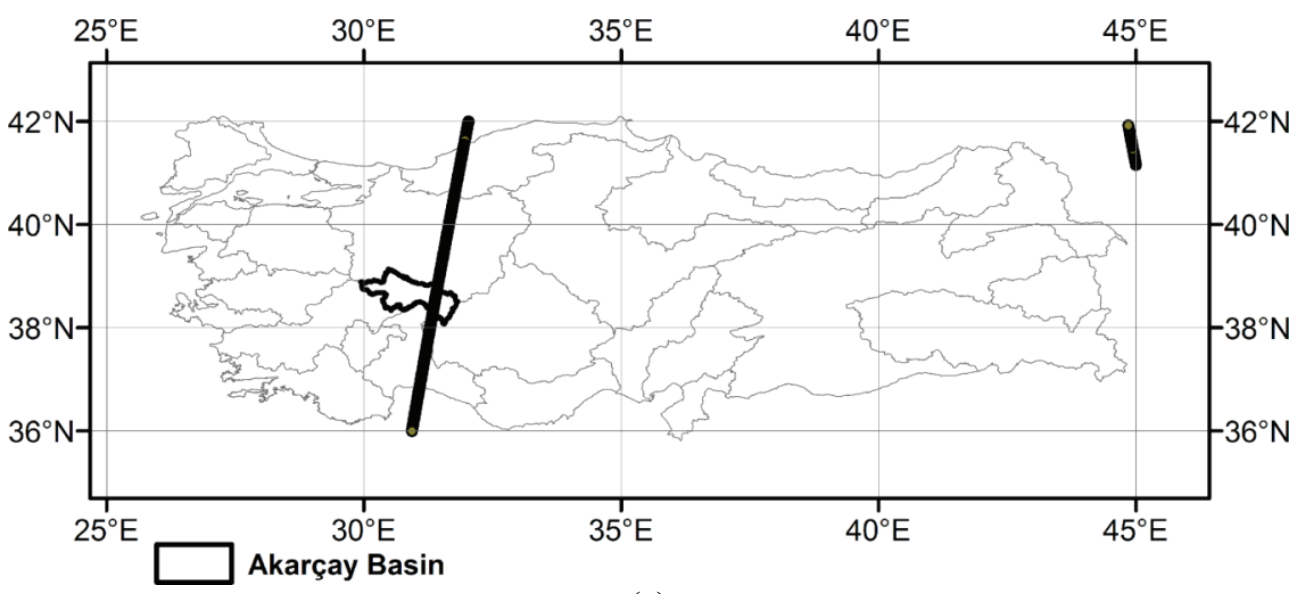

(a)

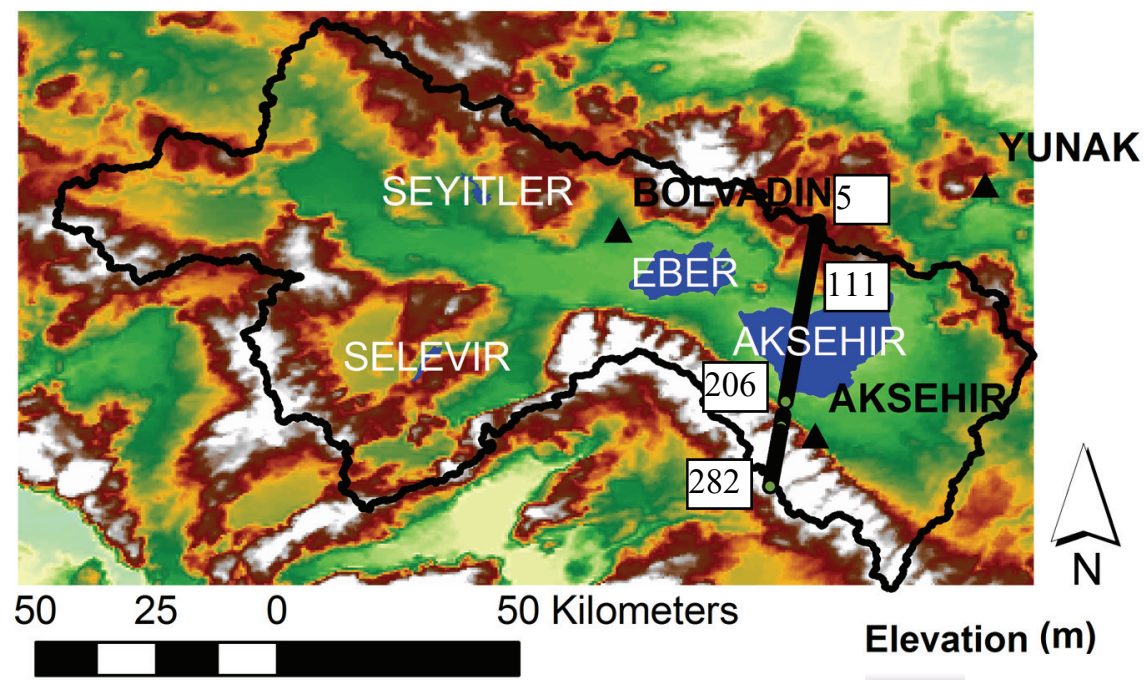

2587

\section{- 23 May 2004 ICESat \\ $\Delta$ Meteorological Stations

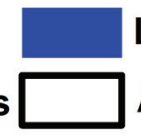 \\ Lakes \\ Akarçay Basin}

774

(b)

Figure 1. Location of Akarçay Basin in Turkey and ICESat data over Turkey for 23 May 2004 (a) Lakes on Digital Elevation Model of Akarçay Basin with meteorological stations and ICESat data over Akarçay Basin for 23 May 2004 (b). 
Located on the migration route of Palearctic birds between Africa and Europe, LR, is also a suitable nesting place for various endemic birds [4]. Some of those birds are under protection [25]. Unfortunately, water levels in most of the lakes in the region are declining [3-5, 21, 26]. $\mathrm{AL} / \mathrm{w}$ is located in a tectonic depression zone at the lowest region (Figure 1b) of Akarçay Basin $\left(7500 \mathrm{~km}^{2}\right)[4,5]$. AL/w has a circular shape and is a shallow lake, as a result, small reductions in water levels result in large areal shrinkage [1]. Water from rainfall and surface runoff replenishes $\mathrm{AL} / \mathrm{w}$, whereas, evaporation and water extraction are the major sources of water losses [5]. Water surface elevations have been recorded during site visits performed once a month since 1975. Şener [3], Yıldırım [4] and Bahadır [5] have indicated water level reductions in $\mathrm{AL} / \mathrm{w}$ in their studies. As a consequence of these reductions, WSE fell below lakes gage level in 2004 since when on site measurements have been abandoned and AL/W totally dried in 2008 [3-5].

\section{DATA SETS}

\subsection{ICESat GLA14}

Ice, Cloud and Land Elevation Satellite (ICESat) is the first satellite-based laser altimeter [27]. ICESat was the benchmark for measuring ice sheet mass balance, cloud and aerosol heights, besides land topography and vegetation characteristics [28]. Geoscience Laser Altimeter System (GLAS) onboard ICESat, makes measurements in $70 \mathrm{~m}$ diameter footprints spaced $172 \mathrm{~m}$ apart. To perform these measurements, for surface altimetry and dense cloud top heights, $1064 \mathrm{~nm}$ laser pulses and $532 \mathrm{~nm}$ laser pulses for vertical distribution of thin clouds and aerosols are utilized [29]. GLAS, measures the duration between the shooting of laser from satellite and return of the related pulse to the satellite following the reflection from Earth's surface and then calculates the range vector. Surface heights are then calculated by subtracting the range vector from GLAS path parameters. If calculated heights pass quality controls and cloud effect checks, they are presented to the end users. Further physical and mathematical details of surface height calculations can be reached from algorithm and theoretical documents [30].

High accuracy $(2 \sim 10 \mathrm{~cm})$ of GLAS derived surface heights over flat regions are already mentioned in scientific literature [31-33]. Among various GLAS data sets, GLAS / ICESat L2 Global Land Surface Altimetry Data (GLA14) which provides surface heights over land, Version 33 is used. Successful applications of GLA14 data sets are shown in literature [22, 34-36]. GLA14 V33 [37] data are obtained from the National Snow and Ice Data Center (NSIDC).

ICESat GLA14 V33 data over Turkey, Akarçay Basin and AL/w from the 23rd of May 2004 are presented in Figures 1a and 1b. Land surface height profile obtained from ICESat data for 23rd of May 2004 (Figure 1b) is shown in Figure 2. Numbers 5, 111, 206 and 282 presented in text boxes in Figure $1 \mathrm{~b}$ correspond to values over the $\mathrm{x}$ axis in Figure 2 and indicate ICESat data starting from entrance of Akarçay Basin at the upper right and going towards the bottom left, passing from the entrance and exit boundary of static vector layer of Akşehir Lake and ending point of Akarçay Basin. 


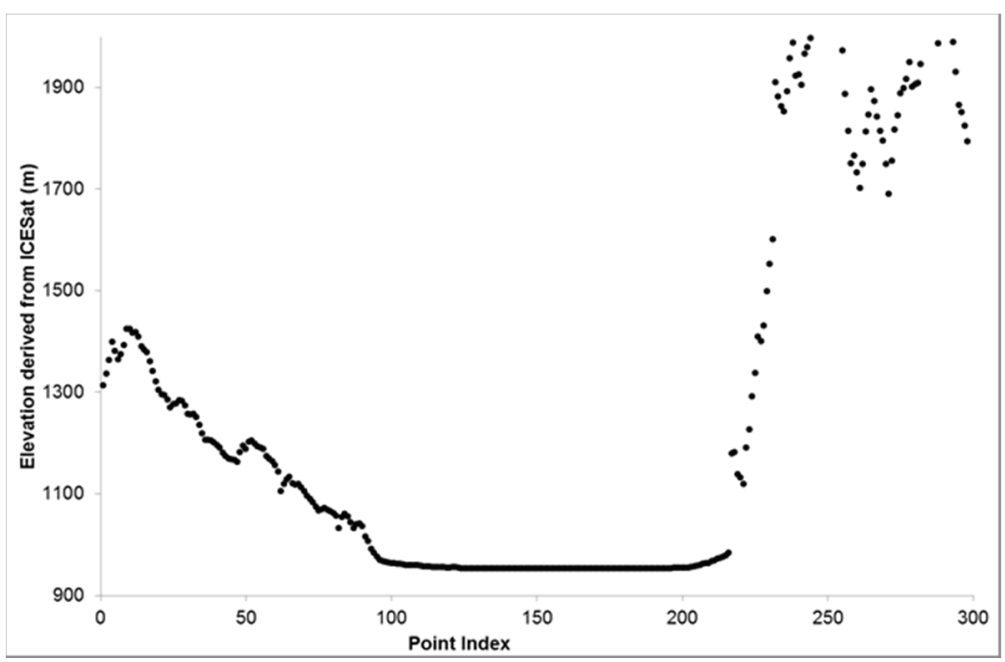

Figure 2. Elevation profile obtained from ICESat GLA14 for 23 May 2004 over Akarçay Basin presented in Figure $1 \mathrm{~b}$.

\subsection{MODIS Daily Snow Cover Maps}

Terra satellite has Moderate Resolution Imaging Spectroradiometer (MODIS), a sensor performing Earth observations through 36 narrow spectrum bands at varying spatial resolutions ranging from 250 to $1000 \mathrm{~m}$. The algorithm developed by Hall et al [38] uses MODIS calibrated radiance data (MOD02HKM), geolocation product (MOD03) and cloud mask product (MOD35_L2) as input [39] to produce MODIS snow-covered area (SCA) maps. MOD10A1, MODIS Snow Cover Daily L3 Global 500m Grid, data from various MODIS snow products was used in this study. In the daily SCA maps, the pixel is assigned to one of the following classes: missing data, no decision, night, no snow, lake, ocean, cloud, lake ice, snow, saturated detector and fill [39]. The high accuracy of MODIS snow-covered area maps has been reported in several studies [39-43]. In addition to those, the usability of MODIS snow-covered area maps of Turkey is shown by [40, 44]. In this study version 5 [45] of MOD10A1 are used.

\section{METHODOLOGY}

Using the Akşehir Lake's static vector file (Figure 3a), the dates of ICESat GLA34 V33 data passing over AL/w were determined. Table 1 summarizes the 14 days that ICESat laser operation coincided with AL/w. The relevant ICESat data was downloaded from NSIDC. A similar approach to Zhang et al. [34]'s work has been applied to downloaded binary files to derive the land surface heights.

Similar to Zhang et al. [22], MODIS SCA maps were used to determine the ICESat footprints that fall on the water surface. However, since water levels in AL/w were declining, daily actual water surfaces which necessitated daily land cover classification were needed. Due to that, each of the MOD10A1 SCA maps for the dates listed in Table 1 was downloaded from the NSIDC and processed. 
Table 1. Dates of ICESat laser periods that overlap Akşehir Lake/Wetland and availability of MODIS snow cover maps.

\begin{tabular}{ccccc}
\hline Laser Operation & Start & End & Overlap AL/w & $\begin{array}{c}\text { MODIS SCA } \\
\text { MOD }\end{array}$ \\
\hline 1AB & $2003-02-20$ & $2003-03-29$ & NA & NA \\
2A & $2003-09-25$ & $2003-11-19$ & $10 / 21 / 2003$ & $\mathrm{~A}^{1}$ \\
2B & $2004-02-17$ & $2004-03-21$ & $2 / 22 / 2004$ & $\mathrm{~A}$ \\
2C & $2004-05-18$ & $2004-06-21$ & $5 / 23 / 2004$ & $\mathrm{~A}$ \\
3A & $2004-10-03$ & $2004-11-08$ & $\mathrm{NA}$ & $\mathrm{NA}$ \\
3B & $2005-02-17$ & $2005-03-24$ & $2 / 23 / 2005$ & $\mathrm{C}$ \\
3C & $2005-05-20$ & $2005-06-23$ & $5 / 25 / 2005$ & $\mathrm{~A}$ \\
3D & $2005-10-21$ & $2005-11-24$ & $10 / 26 / 2005$ & $\mathrm{~A}$ \\
3E & $2006-02-22$ & $2006-03-28$ & $2 / 27 / 2006$ & $\mathrm{~A}$ \\
3F & $2006-05-24$ & $2006-06-26$ & $5 / 29 / 2006$ & $\mathrm{~A}$ \\
3G & $2006-10-25$ & $2006-11-27$ & $10 / 29 / 2006$ & $\mathrm{C}$ \\
3H & $2007-03-12$ & $2007-04-14$ & $3 / 16 / 2007$ & $\mathrm{~A}$ \\
3I & $2007-10-02$ & $2007-11-05$ & $10 / 7 / 2007$ & $\mathrm{~A}$ \\
3J & $2008-02-17$ & $2008-03-21$ & $2 / 22 / 2008$ & $\mathrm{C}$ \\
3K & $2008-10-04$ & $2008-10-19$ & $10 / 8 / 2008$ & $\mathrm{~A}$ \\
2D & $2008-11-25$ & $2008-12-17$ & $\mathrm{NA}$ & $\mathrm{NA}$ \\
2E & $2009-03-09$ & $2009-04-11$ & $\mathrm{NA}$ & $\mathrm{NA}$ \\
2F & $2009-09-30$ & $2009-10-11$ & $10 / 5 / 2009$ & \\
\hline
\end{tabular}

C: Cloud covered A: Available NA: Not Applicable

${ }^{1}$ No ICESat data available over AL/w water surface

Based on the MOD10A1 images, water surface of AL/w were extracted daily (Figure 3a). The water surfaces were transformed into vector files (Figure $3 \mathrm{~b}$ ). To remove the mixed pixels which may be encountered in MODIS [44], $500 \mathrm{~m}$ buffers are applied to water surface vectors (Figure 3c).

ICESat footprints that are actually on the water surfaces (Figure 3a) and outside the $500 \mathrm{~m}$ buffer (Figure 3c) are used to obtain AL/w water surface heights (Figure 3d). Figure 3 shows the static AL/w vector file used for ICESat overlapping dates (Table 1), ICESat foot prints for 23 May 2004 (red dots), AL/w water surface based on MOD10A1 for 23 May 2004 (a), vector of AL/w water surface (b), $500 \mathrm{~m}$ buffer applied to water surface vector (c) and ICESat footprints over the actual water surface that are outside the $500 \mathrm{~m}$ buffer (d). Figure 4 presents the flowchart of the methodology. 


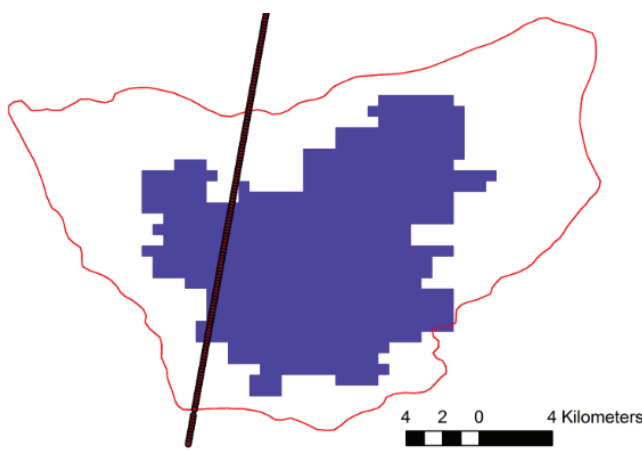

(a)

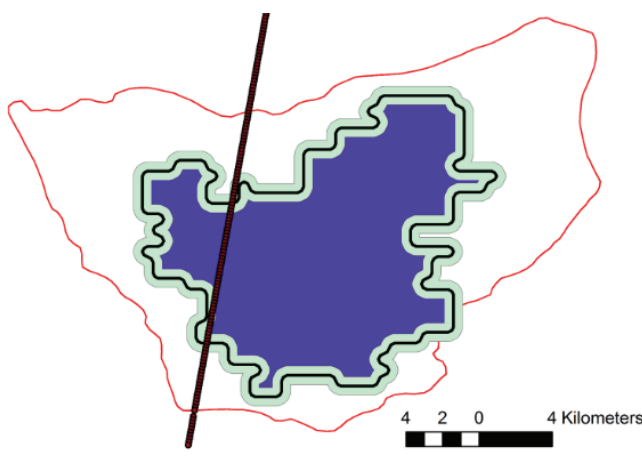

(c)

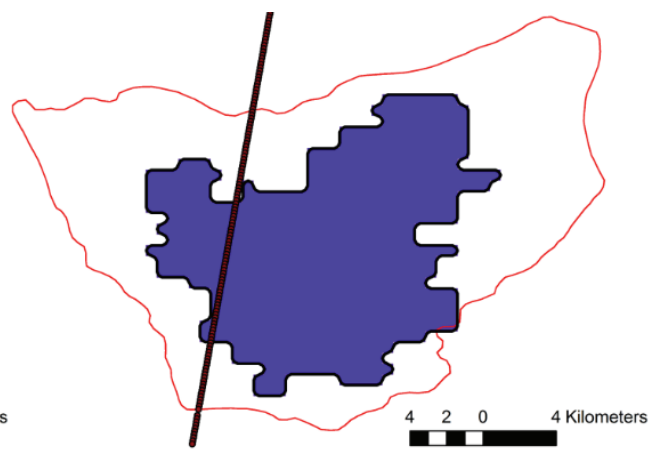

(b)

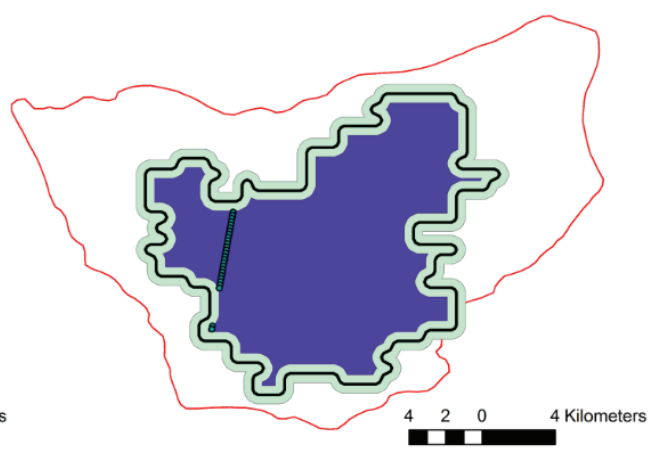

(d)

Figure 3. Static AL/w vector file used in ICESat overlapping dates, ICESat foot prints for 23 May 2004 (red points), AL/w from MOD10A1 (a), vector of AL/w (b), 500 meter buffer applied to Al/w lake vector (c) and ICESat footprints over the actual water surface that are outside the $500 \mathrm{~m}$ buffer (green points)(d).

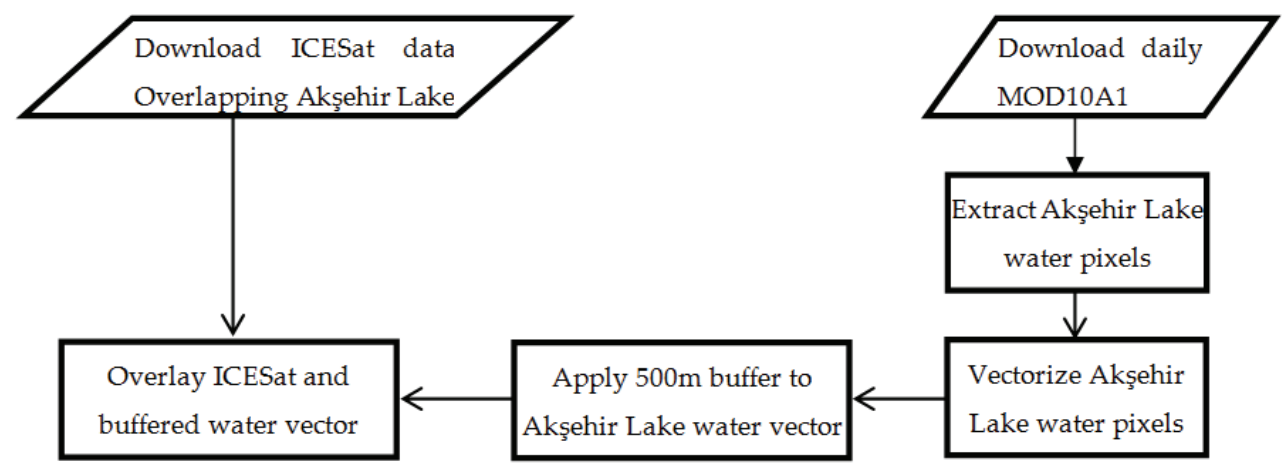

Figure 4. Flowchart of the proposed methodology 


\section{RESULTS}

GLA14 V33 data belonging to 23 May 2004 is clipped for Akarçay Basin and presented in Figure 2. The data set (Figure 2) starts from the medium height mountains $(1200 \mathrm{~m})$ in the north of the $\mathrm{AL} / \mathrm{w}$, decreases as it approaches $\mathrm{AL} / \mathrm{w}$, remains constant over the lake surface and reaches $1900 \mathrm{~m}$ in the mountains forming the southwest boundary of the watershed. These are in agreement with the topography presented as DEM in Figure 1b.

Following the flowchart given in Figure 4 and based on the methodology mentioned in section four, the calculated water surface elevations of $\mathrm{AL} / \mathrm{w}$ is given in Table 2 . The data date, elevation (m), standard deviation (sd) (m) under the ICEM column are derived using the ICESat- MODIS based data sets. As the water level in the AL/w fell below the gage level in 2004, in-situ water level measurements performed once a month were totally abandoned. Therefore, it was not possible to make direct comparisons between ICESAT-based water levels with in-situ gage observations. However, findings in [3-5] were used to obtain water levels in AL/w. Above mentioned studies ([3-5]) investigated the changes in water surface area (WSA) of AL/w using different remote sensing approaches and provided WSAs on different dates. LAB header in Table 2, includes data set which indicates the first author of the group that performed the study among ([3-5]) and data date indicating the date

Table 2. Akşehir Lake/Wetland's water surface elevations obtained from ICESat data and literature surveys.

\begin{tabular}{|c|c|c|c|c|c|c|c|}
\hline \multicolumn{4}{|c|}{ LAB } & \multicolumn{3}{|c|}{ ICEM } & \multirow{2}{*}{$\begin{array}{r}\text { Difference } \\
(\mathrm{m})\end{array}$} \\
\hline Data Set & Data date & Area $\left(\mathrm{km}^{2}\right)$ & $\begin{array}{c}\text { Elevation } \\
(\mathrm{m})\end{array}$ & Data Date & $\begin{array}{c}\text { Elevation } \\
(\mathrm{m})\end{array}$ & $\begin{array}{l}\mathrm{sd} \\
(\mathrm{m})\end{array}$ & \\
\hline \multirow[t]{3}{*}{ Yildırım } & 16 Jun 2002 & 205.133 & 953.71 & & & & \\
\hline & & & & 22 Feb 2004 & 952.01 & 0.34 & \\
\hline & & & & 23 May 2004 & 953.36 & 0.04 & \\
\hline Sener & $!$ & & 953.5 & & & & 0.14 \\
\hline \multirow[t]{2}{*}{ Yildırım } & $!$ & & 953.35 & & & & -0.01 \\
\hline & & & & 25 May 2005 & 952.81 & 0.06 & \\
\hline \multirow[t]{4}{*}{ Bahadır } & 19 Jun 2005 & 113 & 952.72 & & & & -0.09 \\
\hline & & & & 26 Oct 2005 & 951.65 & 0.87 & \\
\hline & & & & 27 Feb 2006 & 952.08 & 0.08 & \\
\hline & & & & 29 May 2006 & 952.38 & 0.04 & \\
\hline Yildırım & 19 Jun 2006 & 110.76 & 952.7 & & & & 0.32 \\
\hline \multirow[t]{2}{*}{ Sener } & 6 Agu2006 & 84.94 & 952.48 & & & & 0.10 \\
\hline & & & & $16 \operatorname{Mar} 2007^{*}$ & 952.28 & 0.15 & \\
\hline \multirow[t]{4}{*}{ Yildırım } & 13 May 2007 & 123.560 & 952.81 & & & & \\
\hline & & & & 7 Oct 2007 & 951.85 & 0.28 & \\
\hline & & & & 8 Oct 2008 & 951.69 & 0.20 & \\
\hline & & & & 5 Oct 2009 & 950.96 & 0.39 & \\
\hline
\end{tabular}

! Exact date could not be found *ICESat data could not satisfy $500 \mathrm{~m}$ buffer criteria 
of the Landsat satellite image acquisition used in analysis. Area column shows the WSA of Akşehir Lake determined by the respective group for the particular day. Using $\mathrm{AL} / \mathrm{W}$ bathymetry data with the lake WSA information obtained from [3-5], respective water surface elevations (WSE) are obtained and these are written in italics in the "Elevation" column in Table 2. The last column in Table 2, Difference, represents the difference in WSE between the LAB and ICEM based methodologies. Elevations and standard deviations obtained by ICEM methodology and AL/w water surface elevations obtained from literature are shown in Figure 5.

The minimum and maximum differences in water surface elevations between LAB and ICEM are $-0.09 \mathrm{~m}$ and $0.32 \mathrm{~m}$, respectively. These values are close to the standard deviations of 0.27 $\mathrm{m}$ and $0.25 \mathrm{~m}$ of the ICESat measurements stated in [22, 34]. Moreover, they show agreement with the $0.21 \mathrm{~m}$ difference between ICESat measurement and in-situ lake observations made on the 27 th of February 2008 mentioned in [34].

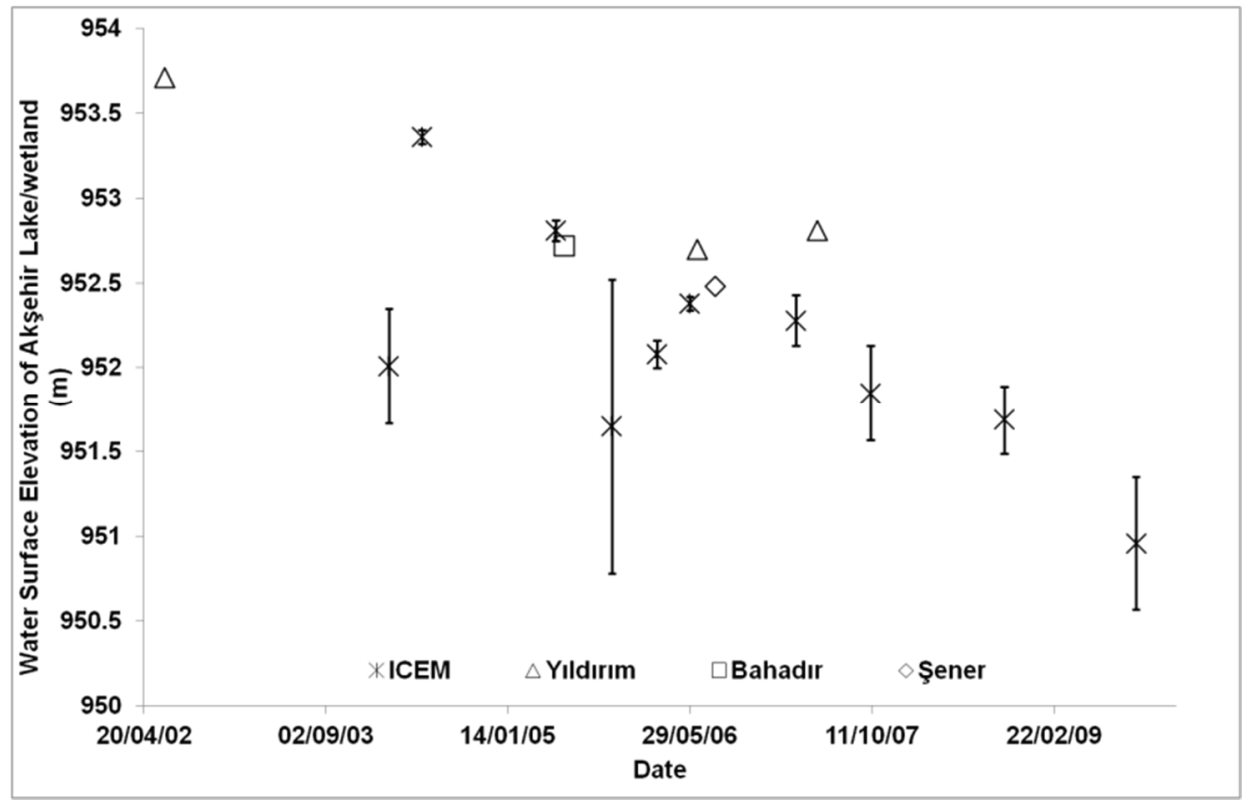

Figure 5. Akşehir Lake/Wetland's water surface elevations obtained from literature surveys and ICEM methodology and its standard deviations.

Bahadir [5] indicated the minimum and maximum water elevation changes between successive winter and spring seasons as 0.4 and $1.78 \mathrm{~m}$. These values were calculated to be $0.30 \mathrm{~m}$ from the 27th of February 2006 to the 29th of May 2006 and $1.35 \mathrm{~m}$ from the 22nd of February 2004 to the 23rd of May 2004 based on ICEM measurements. The values found are within the range specified by [5]. Changes in water levels in successive winter and spring months can be explained by high precipitation [4] and snowmelt runoff $[5,46]$. 


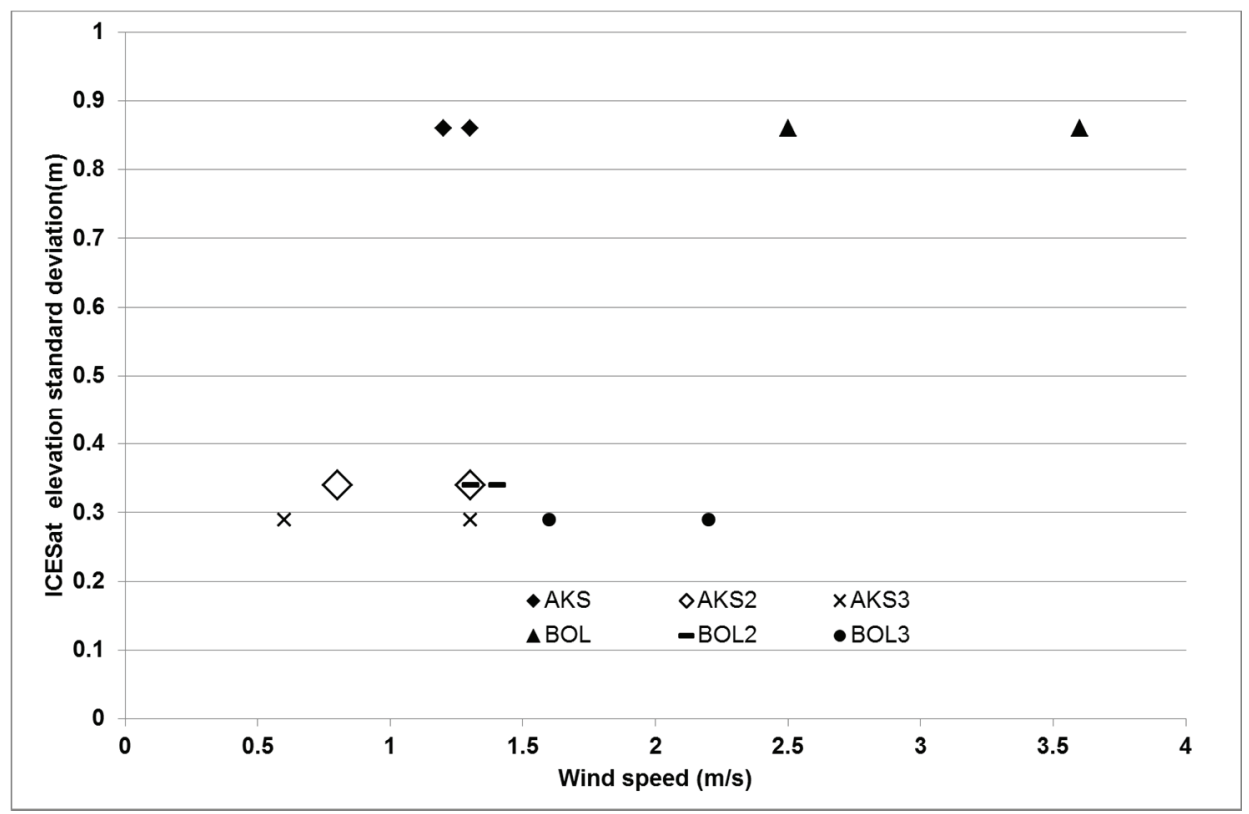

Figure 6. Standard deviation of ICESat derived water surface elevations and wind speeds $(\mathrm{m} / \mathrm{s})$ recorded in Akșehir and Bolvadin meteorological station at the start and end hours of ICESat observations.

Standard deviations (SD) of elevation data obtained by ICEM methodology showed high values in October with the maximum SD calculated as $0.87 \mathrm{~m}$ on 26 October 2005 . This finding is in agreement with the relatively higher wind speeds recorded at Akșehir (AKS) and Bolvadin (BOL) meteorological stations in Akarçay Basin. In both meteorological stations wind speeds are recorded hourly. Figure 6 shows variation of ICESat derived elevation SD and the wind speeds at the AKS and BOL meteorological stations recorded at the start and end hours of ICESat observations, being close to $1.5 \mathrm{~m} / \mathrm{s}$ and greater than 2.5 $\mathrm{m} / \mathrm{s}$ for AKS and BOL stations respectively. For the smaller SD values, wind speeds in AKS and BOL are less than $1.5 \mathrm{~m} / \mathrm{s}$ and $2.5 \mathrm{~m} / \mathrm{s}$. The maximum standard deviation calculated as $0.87 \mathrm{~m}$ on 26 October 2005 fits in the historical observations mentioning about waves reaching up to $1 \mathrm{~m}$ over Akşehir Lake [1]. The high standard deviations observed at ICESat water levels in October are similar to the findings of Zhang et al. [22, 34] and these high standard deviations can be attributed to the wind speeds that play important role in wave heights [47].

\section{CONCLUSIONS}

In this article, it is shown that how satellite onboard sensors working on different regions of electromagnetic spectrum can be combined to augment environmental studies. In this sense, optical sensor MODIS on board Terra satellite and first satellite laser altimetry instrument GLAS on board ICESat data are used in combination (ICEM) to get the water surface 
elevations (WSE) of Akşehir Lake/wetland (AL/w) during its shrinkage and complete dry up in 2008. What makes this study distinct from available ICESat studies is that Akşehir Lake totally dried up in 2008. Thus ICESat data are evaluated during the recession of the lake.

Due to non-existence of ground lake level measurements following the lakes level falling below gage in 2004, WSE had to be calculated using LAB in which; $\mathrm{AL} / \mathrm{w}$ bathymetry is used with Landsat satellite image based water surface areas provided in literature. LAB derived WSE enabled evaluation of ICEM based WSE.

Minimum and maximum differences in WSEs between LAB based studies and ICEM are found to be $-0.09 \mathrm{~m}$ and $0.32 \mathrm{~m}$, respectively. These differences are acceptable considering that data are compiled from various sensors each having various spatial and temporal resolutions and working on different regions of electromagnetic spectrum. Moreover, water surface elevation differences are close to published studies where ICESat-derived water surface elevations are compared with on-site observations.

When ICESat observations over $\mathrm{AL} / \mathrm{w}$ are investigated, it is seen that water levels start to increase during the year from February to May. This is in line with the hydrological characteristics of the basin, as it is inevitable that the snowmelt runoff coming to the lake will cause increases in the water levels. This finding matches with snowmelt runoff importance in $\mathrm{AL} / \mathrm{w}$ indicated by [46]. Water surface elevation increments between consecutive fall and spring seasons were calculated as $0.30-1.35 \mathrm{~m}$ and these are in the historical range indicated by [5].

The primary mission of ICESat was monitoring sea ice [28], which reduced data availability over the study area, $\mathrm{AL} / \mathrm{w}$. Still, many valuable applications can be made using existing ICESat data in combination with other satellite-based Earth observations. The methodology presented here can easily be applied to different regions of the world and can be implemented for ICESat follow-up missions. This study is a solid application of the scientific goal and mission of ICESat2 "Enhancing the utility of other Earth-observation systems through supporting measurements." [48].

\section{Acknowledgements}

The author thanks the National Ice Center for providing MOD10A1 and ICESat GLA14 data. Meteorological data are a courtesy of Turkish State Meteorological Service.

\section{References}

[1] DSI, 2008-2012 Wetland management plans for Akşehir and Eber (Akşehir ve Eber Gölleri Sulak alan yönetim planı 2008-2012), Devlet Su İșleri Genel Müdürlüğü, 2008.

[2] Ramsar, http://www.ramsar.org/wetland/turkey (Last accessed 2 February 2017).

[3] Sener, E., Davraz, A., Sener, S., Investigation of Akşehir and Eber Lakes (SW Turkey) coastline change with multitemporal satellite images, Water Resour. Manage., 24, 727745, 2010, DOI 10.1007/s11269-009-9467-5. 
[4] Yıldırım, Ü., Erdoğan S., Uysal M., Changes in the coastline and water level of the Akşehir and Eber Lakes between 1975 and 2009, Water Resour. Manage., 24,941-962, 2011, DOI: 10.1007/s11269-010-9735-4.

[5] Bahadır M., Akşehir gölü’nde alansal değişimlerin uzaktan algılama teknikleri ile belirlenmesi, Marmara Coğrafya Dergisi, 28, 246-275, 2013.

[6] Smith, L. C., Satellite remote sensing of river inundation area, stage and discharge: a review, Hydrological Processes, 11(10), 1427-1439, 1997.

[7] Munyati, C., Wetland change detection on the Kafue Flats, Zambia, by classification of a multitemporal remote sensing image dataset, International Journal of Remote Sensing, 21, 1787-1806, 2000.

[8] Frazier, P. S., Page, K.J., Water body detection and delineation with Landsat TM data, Photogrammetric Engineering and Remote Sensing, 66, 1461-1467, 2000.

[9] Rokni, K., Ahmad, A., Selamat, A., Hazini S., Water feature extraction and change detection using multitemporal Landsat imagery, Remote Sensing, 6(5), 4173-4189, 2014.

[10] Mueller, N., Lewis, A., Roberts, D., Ring, S., Melrose, R., Sixsmith, J., Lymburner, L., McIntyre, A., Tan, P., Curnow, S., Ip, A., Water observations from space: Mapping surface water from 25 years of Landsat imagery across Australia, Remote Sensing of Environment, 174, 341-352, 2016, doi:10.1016/j.rse.2015.11.003.

[11] White, L., Brisco, B., Dabboor, M., Schmitt, A., Pratt, A., A Collection of SAR Methodologies for Monitoring Wetlands, Remote Sens., 7, 7615-7645, 2015.

[12] Baghdadi, N., Bernier, M., Gautier, R., Neeson, I., Evaluation of Cband SAR data for wetlands mapping, International Journal of Remote Sensing, 22, 71-88, 2001.

[13] Zeng, C., Wang J., Huang, X., Bird, S., Luce, J. J., Urban water body detection from the combination of high-resolution optical and SAR images, Urban Remote Sensing Event (JURSE), 2015 Joint, Lausanne, 2015, 1-4. doi: 10.1109/JURSE.2015.7120525.

[14] Yamazakia, D., Triggb, M. A., Ikeshimac, D., Development of a global $~ 90 \mathrm{~m}$ water body map using multi-temporal Landsat images, Remote Sensing of Environment, 171, 337-351, 2015, doi:10.1016/j.rse.2015.10.014.

[15] Gu, Y.,Wylie B. K., Developing a 30-m grassland productivity estimation map for central Nebraska using 250-m MODIS and 30-m Landsat-8 observations, Remote Sensing of Environment, 171, 291-298, 2015, doi:10.1016/j.rse.2015.10.018.

[16] Wulder, M.A., Whitea, J. C., Lovelandb, T. R., Woodcockc, C. E., Belwardd, A. S., Cohene, W. B., Fosnightb, E. A., Shawf, J., Masekg, J. G., Royh, D. P., The global Landsat archive: Status, consolidation, and direction, Remote Sensing of Environment, 185,271-283, 2015, doi:10.1016/j.rse.2015.11.032.

[17] Fisher, A., Flood, N., Danaher, T., Comparing Landsat water index methods for automated water classification in eastern Australia, Remote Sensing of Environment, 175, 167-182, 2016, doi:10.1016/j.rse.2015.12.055. 
[18] Song, X.-P., Sexton, J. O., Huang, C., Channan, S., Townshend, J. R., Characterizing the magnitude, timing and duration of urban growth from time series of Landsat-based estimates of impervious cover, Remote Sensing of Environment, 175, 1-13, 2016, doi:10.1016/j.rse.2015.12.027.

[19] Neigha, C. S.R., Maseka, J. G., Bourgetb, P., Rishmawic, K., Zhaoc, F., Huangc, C., Cooka, B. D., Nelsona, R.F., Regional rates of young US forest growth estimated from annual Landsat disturbance history and IKONOS stereo imagery, Remote Sensing of Environment, 173, 282-293, 2016, doi:10.1016/j.rse.2015.09.007.

[20] Ormeci, C., Ekercin, S., An assessment of water reserve changes in Salt Lake, Turkey, through multi-temporal Landsat imagery and real-time ground surveys, Hydrol Process, 21, 1424-1435, 2007, DOI: 10.1002/hyp.6355.

[21] Reis, S., Yilmaz, H. M., Temporal monitoring of water level changes in Seyfe Lake using remote sensing, Hydrological Processes, 22, 4448-4454, 2008, doi:10.1002/hyp.7047.

[22] Zhang, G. ,Xie, H., Kang, S. ,Yi, D. and Ackley, S. F., Monitoring lake level changes on the Tibetan Plateau using ICESat altimetry data (2003-2009), Remote Sens. Environ, 115(7), 1733-1742, 2011.

[23] https://tr.wikipedia.org/wiki/Göller_Yöresi (Last accessed 2 February 2017)

[24] Çatal, A. ve Dengiz, O., Akşehir gölünün Akşehir çölüne dönüşü süreci ve etki eden faktörler, Toprak Su Dergisi, 4(1),18-26, 2015

[25] Birdlife International, http://www.birdlife.org/datazone/sitefactsheet.php?id=765 (Last accessed 2 February 2017)

[26] Durduran, S.S., Coastline change assessment on water reservoirs located in the Konya Basin Area, Turkey, using multitemporal landsat imagery, Eviron Monit Assess, 164, 453-461, 2010 doi:10.1007/s10661-009-0906-9.

[27] Zwally, H. J., Schutz, B., Abdalati, W., Abshire, J., Bentley, C., Brenner, A., et al., ICESat's laser measurements of polar ice, atmosphere, ocean, and land, Journal of Geodynamics, 34(3-4), 405-445, 2002.

[28] ICESat. https://icesat.gsfc.nasa.gov/icesat/index.php (Last accessed 11 February 2017)

[29] Spinhirne, J. D., S. P. Palm, W. D. Hart, D. L. Hlavka, and E. J. Welton, Cloud and aerosol measurements from GLAS: Overview and initial results, Geophys. Res. Lett., 32, L22S03, 2005, doi:10.1029/2005GL023507.

[30] NSIDC, http://nsidc.org/data/docs/daac/glas_icesat_11_12_global_altimetry.gd.html, (Last accessed 23 February 2017)

[31] Kwok, R., Zwally, H. J., Yi, D., ICESat observations of Arctic sea ice: a first look. Geophysical Research Letters, 31, L16401, 2004

[32] Srivastava, P., Bhambri, R., Kawishwar, P., Dobhal, D. P., Water level changes of high altitude lakes in Himalaya-Karakoram from ICESat altimetry, J. Earth Syst. Sci.122, 1533-1543, 2013. 
[33] Khvorostovsky, K., Rampal, P., On retrieving sea ice freeboard from ICESat laser altimeter, The Cryosphere, 10, 2329-2346, 2016.

[34] Zhang, G., Xie H., Duan S., Tian, M., and Yi, D., Water level variation of Lake Qinghai from satellite and in situ measurements under climate change, $\mathrm{J}$ of Applied Remote Sensing, 2011

[35] Ke, L., Dinga, X., Song, C., Heterogeneous changes of glaciers over the western Kunlun Mountains based on ICESat and Landsat- 8 derived glacier inventory, Remote Sensing of Environment, 168, 13-23, 2015, doi:10.1016/j.rse.2015.06.019.

[36] Wang, Y., Li, G., Ding, J., Guo, Z., Tang, S., Wang, C., Huang, Q., Liu, R., Chen, J. M., A combined GLAS and MODIS estimation of the global distribution of mean forest canopy height, Remote Sensing of environment, 174, 24-43, 2016, doi:10.1016/j.rse.2015.12.00.

[37] Zwally, H. J., R. Schutz, and J. Abshire. 2011. GLAS/ICESat L1A Global Laser Pointing Data, Version 33. Boulder, Colorado USA. NASA National Snow and Ice Data Center Distributed Active Archive Center. doi: https://doi.org/10.5067/ICESAT/GLAS/DATA124.

[38] Hall, D. K., Riggs, G. A., Salomonson, V. V., Development of methods for mapping global snow cover using moderate resolution imaging spectroradiometer data, Remote Sens Environ, 54:127-14, 1995.

[39] MODIS. http://modis.gsfc.nasa.gov/data/dataprod/mod10.php (Last accessed 21 Şubat 2017)

[40] Tekeli, A. E., Akyürek, Z, Şorman, A. A., Şensoy, A., Şorman, A. U., Using MODIS snow cover maps in modeling snowmelt runoff process in the eastern part of Turkey, Remote Sens Environ, 97, 216-230, 2005.

[41] Gafuorov A., Vorogushyn S., Farinotti D., Duethmann D., Merkushkin A., Merz B., Snow-cover reconstruction methodology for mountainous regions based on historic in situ observations and recent remote sensing data, The Cryosphere, 9, 451-463, 2015.

[42] Xu W., Ma H., Wu D., Yuan W., Assessment of the Daily Cloud-Free MODIS SnowCover Product for Monitoring the Snow-Cover Phenology over the Qinghai-Tibetan Plateau, Remote Sens, 9(6),585, 2017

[43] Pu, Z., Xu, L., Salomonson, V. V., MODIS/Terra observed seasonal variations of snow cover over the Tibetan Plateau, Geopyhs Res Lett, 34:L06706., 2007 doi:10,1029/2007GL029262

[44] Tekeli, A. E., Sensoy, A., Sorman, A. A., Akyurek, Z., Sorman, A. U., Accuracy assessment of MODIS daily snow albedo retrievals with in situ measurements in Karasu Basin, Turkiye, Hydrological Processes, 20, 705-721, 2006.

[45] Hall, D. K., V. V. Salomonson, and G. A. Riggs. 2006. MODIS/Terra Snow Cover Daily L3 Global 500m Grid, Version 5. Boulder, Colorado USA. NASA National Snow and Ice Data Center Distributed Active Archive Center. doi: https://doi.org/10.5067/63NQASRDPDB0. 
[46] Dönmez S. “Assessing Akşehir Lake's recession using meteorological and satellite data" (in Turkish). Journal of The Faculty of Engineering and Architecture of Gazi University. 33 (1), 177-188,2018, doi:10.17341/gazimmfd.406790.

[47] Wever N. "Quantifying trends in surface roughness and the effect on surface wind speed observations". Journal of Geophysical Research, Vol. 117, D11104, doi:10.1029/2011JD017118. 2012

[48] ICESat2. http://icesat.gsfc.nasa.gov/icesat2/science_objs.php (Last accessed 20 February 2017). 
